\title{
Biodistribution of samarium-153-EDTMP in rats treated with docetaxel ${ }^{1}$
}

\author{
Biodistribuição de EDTMP-153-samário em ratos tratados com docetaxel
}

\author{
Arthur Villarim NetoI, Maria Kadja Meneses Torres Açucena ${ }^{I}$, Kércia Regina Santos Gomes PereiraI, Amália Cínthia Meneses \\ Rêgo', Ítalo Medeiros Azevedo", Mário Bernardo-Filho"II, Aldo Cunha Medeiros ${ }^{\mathrm{IV}}$

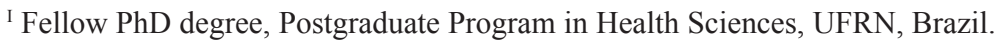 \\ II Statistician, Department of Surgery, UFRN, Brazil. \\ III PhD, Full Professor, Department of Biophysics and Biometry, State University of Rio de Janeiro, Brazil. \\ Iv $\mathrm{PhD}$, Full Professor, Department of Surgery, UFRN, Brazil.
}

\begin{abstract}
Purpose: Many patients with metastatic bone disease have to use radiopharmaceuticals associated with chemotherapy to relieve bone pain. The aim of this study was to assess the influence of docetaxel on the biodistribution of samarium-153-EDTMP in bones and other organs of rats. Methods: Wistar male rats were randomly allocated into 2 groups of 6 rats each. The DS (docetaxel/samarium) group received docetaxel $(15 \mathrm{mg} / \mathrm{kg})$ intraperitoneally in two cycles 11 days apart. The $\mathrm{S}$ (samarium/control) group rats were not treated with docetaxel. Nine days after chemotherapy, all the rats were injected with $0.1 \mathrm{ml}$ of samarium-153-EDTMP via orbital plexus $(25 \mu \mathrm{Ci})$. After 2 hours, the animals were killed and samples of the brain, thyroid, lung, heart, stomach, colon, liver, kidney and both femurs were removed. The percentage radioactivity of each sample (\% ATI/g) was determined in an automatic gamma-counter (Wizard-1470, Perkin-Elmer, Finland). Results: On the $9^{\text {th }}$ day after the administration of the $2^{\text {nd }}$ chemotherapy cycle, the rats had a significant weight loss $(314.50 \pm 22.09 \mathrm{~g})$ compared $(\mathrm{p}<0.5)$ to pre-treatment weight $(353.66 \pm 22.8)$. The $\% \mathrm{ATI} / \mathrm{g}$ in the samples of rats treated with samarium-153-EDTMP had a significant reduction in the right femur, left femur, kidney, liver and lungs of animals treated with docetaxel, compared to the control rats. Conclusion: The combination of docetaxel and samarium-153-EDTMP was associated with a lower response rate in the biodistribution of the radiopharmaceutical to targeted tissues. Further investigation into the impact of docetaxel on biodistribution of samarium-153-EDTMP would complement the findings of this study.
\end{abstract}

Key words: Taxoids. Samarium. Biological Availability. Drug Therapy. Rats.

\section{RESUMO}

Objetivo: Muitos pacientes com metástases ósseas são tratados com radiofármacos associados com quimioterapia para alívio da dor óssea. O objetivo do trabalho foi estudar a influência do docetaxel na biodistribuição do EDTMP-153-samário nos ossos e outros órgãos de ratos. Métodos: Ratos Wistar foram aleatoriamente alocados em 2 grupos de 6 animais cada. O grupo DS (docetaxel/samário) recebeu docetaxel $(15 \mathrm{mg} / \mathrm{kg}$ ) intraperitoneal em dois ciclos com 11 dias de intervalo. Os ratos do grupo S (samário/controle) não foram tratados com docetaxel. Nove dias após a quimioterapia, todos os animais receberam 0,1ml de EDTMP-153-samário via plexo orbital $(25 \mu \mathrm{Ci})$. Após 2 horas, os animais foram mortos e feitas biópsias de cérebro, tireóide, pulmão, coração, estômago, cólon, fígado, rim e fêmures. O percentual de radioatividade por grama (\%ATI/g) de tecido de cada biópsia foi determinado em contador gama automático (Wizard-1470, Perkin-Elmer, Finland). Resultados: No $9^{\circ}$ após $2^{\circ}$ ciclo de docetaxel os ratos tiveram perda de peso significante,

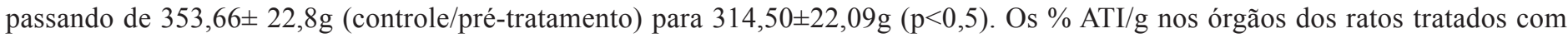
EDTMP-153-samário e docataxel tiveram redução significante nos fêmures direito e esquerdo, rim, fígado e pulmão, quando comparados com os não tratados com docetaxel. Conclusão: A combinação de docetaxel com EDTMP-153-samário foi associada com resposta mais baixa na biodistribuição do radiofármaco em órgãos alvo. Futuras investigações sobre o impacto do docetaxel na biodistribuição do EDTMP-153-samário poderão complementar os achados teste estudo.

Descritores: Taxóides. Samário. Disponibilidade Biológica. Quimioterapia. Ratos.

${ }^{1}$ Research performed at the Postgraduate Program in Health Sciences, Federal University of Rio Grande do Norte (UFRN), Brazil. 


\section{Introduction}

Bone metastases are a frequent complication of cancer, occurring in up $70 \%$ of patients suffering from advanced breast or prostate cancer ${ }^{1}$. Bone metastases patients often present with severe bone pain, especially in the advanced stage of disease ${ }^{1,2}$. The major pain mechanism of small metastases appears to be the stimulation of nerve endings in the endosteum by a variety of chemical mediators. Larger bone metastases produce stretching of the periosteum, which leads to pain ${ }^{2}$. The resulting bone pain interferes with the patient's quality of life and requires effective treatment. Unfortunately, various non-radiotherapeutic modalities such as analgesics, hormone therapy, orchidectomy, cytostatic and cytotoxic drugs, bisphosphonates, and surgery are not effective in all cases, especially in the late stage of the disease $\mathrm{e}^{1,2}$. Systemic radionuclide therapy using boneseeking radiopharmaceuticals is considered a valuable and effective method for treating patients with widespread skeletal metastases and increased bone turnover, especially in patients with bone metastases from prostate and breast cancer $^{3,4,5}$.

In the 1980s the radiopharmaceutical samarium-153 ethylenediamine tetramethylene phosphonate (Sm-153-EDTMP) with short physical half-life was developed, and has been considered effective in the treatment of bone pain ${ }^{4,5}$. Docetaxel is one of the taxane class chemotherapies that is being increasingly used to treat various solid tumors, including those of prostate and breast cancer. It acts by Bcl-2 protein inactivation in the metastatic cells, causing the death of tumor cells by apoptosis ${ }^{6}$. In patients with prostate cancer, docetaxel has been suggested in various studies as the first-line choice for treating metastatic hormone-refractory disease. This treatment increases survival, compared to previously accepted chemotherapy schemes ${ }^{6}$.

A significant number of patients with metastatic bone disease are often subjected to a series of concomitant treatments, including the use of radioisotopes to relieve bone pain, associated with chemotherapy. Accordingly, the aim of this study was to assess the influence of docetaxel on the biodistribution of Sm-153-EDTMP, especially in the bones of rats, enabling a more thorough knowledge of its applicability.

\section{Methods}

We used male rats provided by the Health Science Center vivarium, Federal University of Rio Grande do Norte, Brazil. The animals were randomly allocated into 2 groups of 6 rats each. They were weighed and placed in individual cages with water and food (Labina Purina $^{\circledR}$ ) "ad libitum" and acclimatized in the lab for 7 days. The rats were kept under temperature $\left(21^{\circ} \mathrm{C}\right)$, humidity (60 - 70\%) and lighting (12 / 12 hour cycle light / dark) control and they were handled in accordance with International Standards of Care and Use of Laboratory Animals, following the guidelines of the Brazilian College of Animal Experimentation.

The animals of the DS group (docetaxel/samarium) were administered docetaxel (Trixotene ${ }^{\circledR}$, Novartis, São Paulo, Brazil), intraperitoneally, using a $15 \mathrm{mg} / \mathrm{kg}$ dose in two administration cycles 11 days apart. The $\mathrm{S}$ group (samarium/control) rats were not treated with docetaxel. The animals remained under observation for 9 days after the $2^{\text {nd }}$ cycle and were then injected with 0.1 $\mathrm{mL}$ of Sm-153-EDTMP via the orbital plexus, corresponding to radioactivity of $925 \mathrm{~Bq}(25 \mu \mathrm{Ci})$. Two hours after radiopharmaceutical administration, the animals were killed with an anesthesia overdose (thiopental sodium, via the intracardiac cannula) and underwent surgery for removal of samples from the brain, thyroid, lung, heart, stomach, colon, liver, kidney and both femurs. The tissue samples were washed in $0.9 \%$ saline, weighed on a precision scale (Mark $160^{\circledR}$, Bel equipment, Italy) and their radioactivity was determined in an automatic gamma counter (Wizard 1470, Perkin-Elmer, Finland). The results are shown in counts per minute (CPM), corrected by disintegrations per minute (DPM). The efficiency of the gamma counter was $86 \%$, as specified by the manufacturer. The specific activity of each sample was calculated by dividing its absolute count DPM by its weight $(\mathrm{DPM} / \mathrm{g})$. The percentage of radioactivity of each sample ( $\%$ ATI $/ g$ ) was calculated by dividing its specific activity (DPM/g) by the total radioactivity injected in each animal. The total activity administered to each animal was calculated from the average of three patterns with the same volume injected.

The data were expressed as mean \pm standard deviation. Statistical analysis for comparison between groups was performed by the Student and Tukey tests, using a significance level of 0.05 .

\section{Results}

No animal died during the experiment. On the eleventh day after the $1^{\text {st }}$ chemotherapy cycle with docetaxel, the animals showed weight loss (mean 329.16 $\pm 29.2 \mathrm{~g}$ ), but not significantly different from pre-treatment weight (mean 353.66 \pm 22.8). Meanwhile, on the $9^{\text {th }}$ day after administration of the $2^{\text {nd }}$ chemotherapy cycle, there was significant weight loss $(314.50 \pm 22.09 \mathrm{~g})$ compared to pre-treatment weight (Figure 1). We observed no changes in animal behavior or side effects, such as diarrhea and hair loss. During the laparotomy to remove organ samples, few peritoneal adhesions were observed in DS group rats. No macroscopic changes were detected in the abdominal organs.

The analysis of the percentage of total activity of Sm-153-EDTMP injected per gram of tissue (\% ATI/g) in the samples analyzed showed greater radiopharmaceutical activity in the liver, kidney, right femur, left femur and thyroid, when compared to other organs, in both the DS group (treated with docetaxel) and control group $\mathrm{S}$ (Table 1). In the rats treated with docetaxel, the Sm-153-EDTMP activity was smaller in all the organs studied, when compared to the control group, except in the brain. Using the Student t-test, we showed that this reduction was statistically significant in the right femur, left femur, kidney, liver and lungs of animals treated with docetaxel, compared to the control group rats $(p<0.05)$. Consequently, there was no significant reduction in radioactivity biodistribution in brain, thyroid, heart, stomach and colon samples (Table 1). 


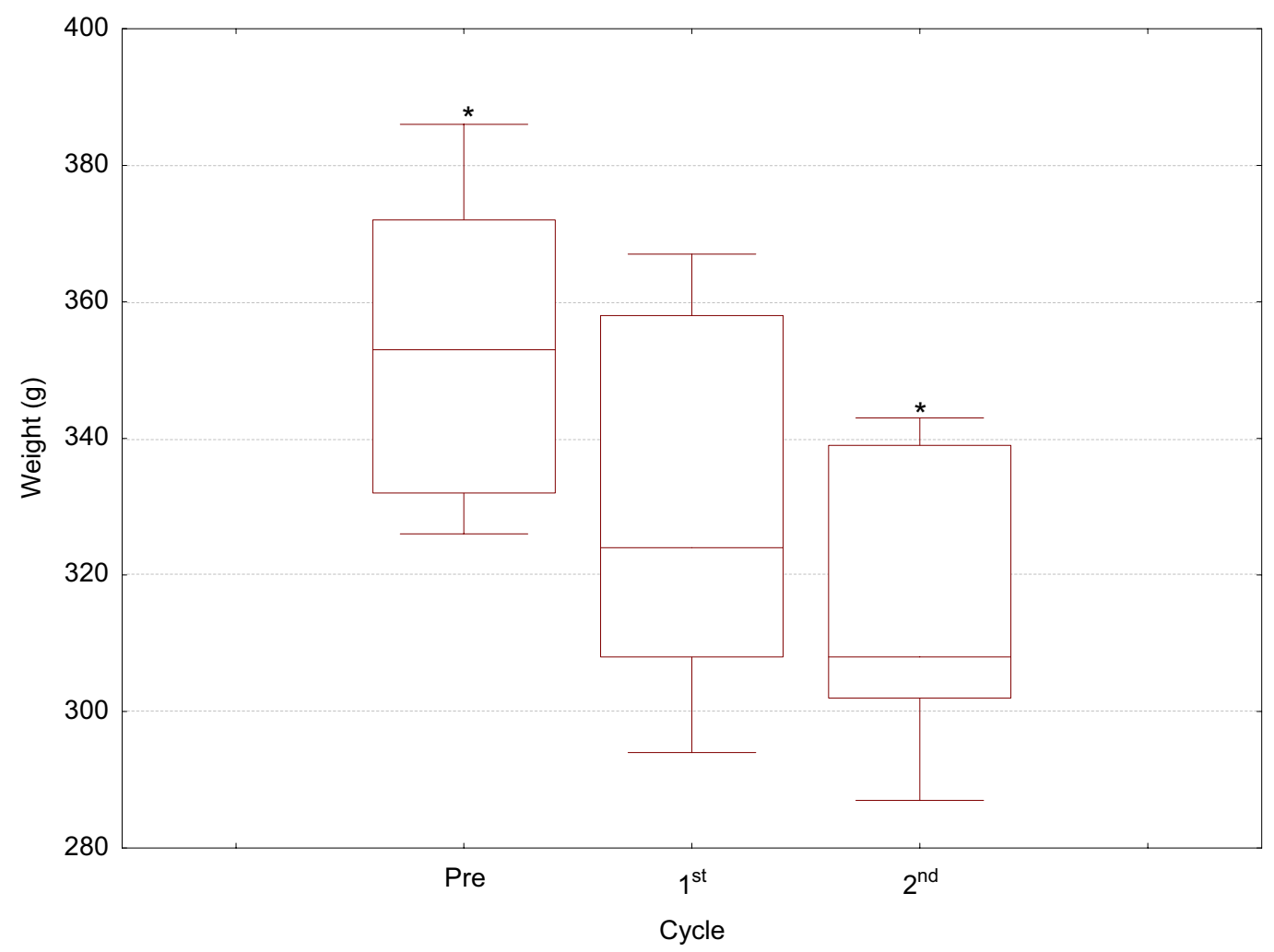

FIGURE 1 - The evolution of rats weight comparing pretreatment and after the first $\left(1^{\text {st }}\right)$ and second $\left(2^{\text {nd }}\right)$ post-docetaxel treatment

* Significant difference, $\mathrm{p}<0.05$, Tukey test.

TABLE 1 - Comparison of percentage of radioactivity/g (\% ATI/g) of samples from each organ of rats treated with Sm153-EDTMP (group S) and with docetaxel + Sm-153-EDTMP (group DS)

\begin{tabular}{c|cc|c}
\hline \multirow{2}{*}{ Organs } & \multicolumn{2}{|c|}{$\%$ ATI/g } & \multirow{2}{*}{$\mathrm{p}$} \\
\cline { 2 - 3 } & Group S & Group DS & \\
\hline Brain & $0.01 \pm 0.002$ & $0.01 \pm 0.005$ & 0.753022 \\
Thyroid & $0.40 \pm 0.079$ & $0.30 \pm 0.066$ & 0.07301 \\
Lung & $0.17 \pm 0.033$ & $0.13 \pm 0.025$ & 0.043126 \\
Heart & $0.12 \pm 0.019$ & $0.11 \pm 0.019$ & 0.300239 \\
Stomach & $0.18 \pm 0.042$ & $0.14 \pm 0.032$ & 0.091458 \\
Colon & $0.13 \pm 0.041$ & $0.11 \pm 0.038$ & 0.484202 \\
Liver & $1.48 \pm 0.187$ & $0.96 \pm 0.267$ & 0.007438 \\
Kidney & $1.21 \pm 0.160$ & $0.86 \pm 0.144$ & 0.007411 \\
Femur (right) & $0.73 \pm 0.105$ & $0.46 \pm 0.093$ & 0.002484 \\
Femur (left) & $0.72 \pm 0.004$ & $0.50 \pm 0.086$ & 0.003599 \\
\hline
\end{tabular}

Mean \pm SD, Student $t$ test. S, samarium; DS, docetaxel+samarium. 


\section{Discussion}

Bone pain is a common symptom of metastatic cancer and may be difficult to control with analgesic medication alone. Systemic agents such as chemotherapy, bisphosphonates and hormonal therapy, as well as external beam radiation in the form of hemibody or focal bone irradiation are also used as palliative measures to control metastatic bone pain ${ }^{7}$. Radiation in the form of radiopharmaceuticals has been investigated for the relief of bone metastasis pain and several systemically administered beta-emitters have been evaluated for the treatment of painful bone metastases, two of which (32-P and 89-Sr) have been studied extensively ${ }^{7}$. Both agents are effective in relieving pain from osteoblastic metastases, but they have properties that limit their usefulness. The very high beta energy of 32-P coupled with a low lesion-to-normal bone ratio has inhibited widespread use of this radiopharmaceutical as a palliative agent for bone pain ${ }^{7}$. The long physical half-life of 89-Sr (50.5 days) results in a slow delivery of the radiation dose. Consequently, the onset of pain relief may not occur for several weeks after administration ${ }^{8}$. The long half-life can also produce a prolonged and variable suppression of hematopoietic elements, limiting the availability or efficacy of concurrent myelosuppressive therapies (e.g. external radiation, surgery or chemotherapy) that these patients frequently require. Therefore, we used 153-samarium in this study because of its physical and biological proprieties, ease of use in laboratory, as well as its efficacy in treating bone pain ${ }^{5}$. The physical half-life of $153-\mathrm{Sm}$ is $46.3 \mathrm{~h}$, and its beta particle has a maximum range of $1.7 \mathrm{~mm}$ in bone and $3.1 \mathrm{~mm}$ in soft tissue. The gamma emission at $103 \mathrm{keV}$ (29\% abundance) is suitable energy for imaging using standard scintigraphic cameras, and is low enough result in minimal external exposure levels when administered at therapeutic levels ${ }^{9}$. Although many radiopharmaceuticals have been examined for bone pain palliation, samarium-153 has been the most extensively examined in clinical trials. The advantages of radiopharmaceutical use include the ease of administration, the ability to treat multiple sites of metastatic disease, the improved potential therapeutic ratio due to bone location and the potential of combining with chemotherapy agents and external beam radiation for an enhanced therapeutic effect ${ }^{4,5}$. A subset of trials has suggested improved pain palliation by combining a radiopharmaceutical agent with chemotherapy $\mathrm{y}^{4,5,12}$.

Taxanes (docetaxel and paclitaxel) are currently one of the most extensively studied new chemotherapeutic agents for metastatic breast cancer. Single-agent docetaxel has demonstrated significant survival advantages over other recognized regimens in two trials involving patients with anthracycline-pretreated metastatic breast cancer ${ }^{10}$. Some data suggest that docetaxel is one of the most active agents available for treating these patients ${ }^{11}$

The primary objective of this study was to evaluate if combined chemotherapy interferes with the biodistribution of Sm-153-EDTMP to bone and other organs. It was based on the possibility of using Sm-153-EDTMP combined with docetaxel for the treatment of bone metastasis pain in patients with prostate or breast cancer. Recently, Ricci et al. ${ }^{12}$ reported that $\mathrm{Sm}-153$ EDTMP is effective in bone pain relief, with minimal toxicity. When administered in combination with chemotherapy (estramustine phosphate or mitoxantrone plus prednisone), it prolonged survival.
Many factors, such as drug therapy, radiation therapy, surgery, in addition to the pathological process, could affect the biodistribution of different radiopharmaceuticals ${ }^{13-15}$. In this work, when Sm-153-EDTMP was administered to rats previously treated with docetaxel, the biodistribution of the radiopharmaceutical to bone, kidney, liver and lung was significantly lower than that of controls. Based on these data, we can infer that an additional dose of Sm-153-EDTMP may be necessary to get the desired pain relief effect when docetaxel is used in combination with this radiopharmaceutical. It was reported that the average duration of bone pain palliation in patients treated with Sm-153-EDTMP alone was about 3-4 months, while it was about 9-10 months in patients who started receiving estramustine phosphate or mitoxantrone plus prednisone after treatment with the bone-seeking radionuclide ${ }^{12}$. However, information about the clinical effect of docetaxel associated to Sm-153-EDTMP is scarce. The results obtained in the present work provide a rationale for further studies aimed at assessing combined chemotherapy and bone-targeted radiotherapy (docetaxel plus Sm-153-EDTMP) as a therapeutic strategy in patients with advanced hormone resistant prostate cancer.

In conclusion, the combination of docetaxel and Sm-153EDTMP was associated with a lower response rate in the biodistribution of the radiopharmaceutical to targeted tissues. Further investigation into the impact of docetaxel on the biodistribution of Sm-153-EDTMP would complement the findings of this study.

\section{References}

1. Liepe K, Runge R, Kotzerke J. The benefit of bone-seeking radiopharmaceuticals in the treatment of metastatic bone pain. J Cancer Res Clin Oncol. 2005;131:60-6.

2. Nielsen OS, Munro AJ, Tannock IF. Bone metastases: pathophysiology and management policy. J Clin Oncol. 1991;9:509-24.

3. Sapienza MT, Ono CR, Guimaraes MI, Watanabe T, Costa PA, Buchpiguel CA. Retrospective evaluation of bone pain palliation after samarium-153-EDTMP therapy. Rev Hosp Clin Fac Med São Paulo. 2004;59:321-8.

4. Ubieto MA, Abos MD, Tardin AL, Razola P, Prats E, Garcia F, Polo E, Yubero A, Banzo J. Treatment of bone metastatic pain with Sm-153EDTMP. Evaluation of the analgesic response and the existence of differences according to the primary tumor and the metastatic pattern. Rev Esp Med Nucl. 2005;24:297-304.

5. Serafini AN. Systemic metabolic radiotherapy with samarium-153 EDTMP for the treatment of painful bone metastasis. Q J Nucl Med. 2001;45:91-9.

6. Petrilak DP, Pangen CM, Hussain MH, Lara PN Jr, Jones JA, Taplin MA, Burch PA, Berry D, Moinpour C, Kohli M, Benson MC, Small EJ, Raghavan D, Crawford ED. Docetaxel and estramustine compared with mitoxantrone and prednisone for advanced refractory prostate cancer. $\mathrm{N}$ Engl J Med. 2004;351:1513-20.

7. Serafini AN. Current status of systemic intravenous radiopharmaceuticals for the treatment of painful metastatic bone disease. Int J Radiat Oncol Biol Phys. 1994;30:1187-94.

8. Laing AH, Ackery DM, Bayly RJ, Buchanan RB, Lewington VJ, McEwan AJ, Macleod PM, Zivanovic MA. Strontium-89 chloride for pain palliation in prostatic skeletal malignancy. Br J Radiol. 1991;64:816-22.

9. Eary JF, Collins C, Stabin M, Vernon C, Petersdorf S, Bakre M, Hartnett S, Ferency S, Addison SJ, Appelbaum F. Samarium-153-EDTMP biodistribution and dosimetry estimation. J Nucl Med. 1993;34:1031-6. 
10. Mabholtz JM, Senn HJ, Bezwoda WR, Melnychuk D, Deschenes L, Douma J, Vandenberg TA, Rapoport B, Rosso R, Trillet-Lenoir V, Drbal J, Molino A, Nortier JW, Richel DJ, Nagykalnai T, Siedlecki P, Wilking N, Genot JY, Hupperets PS, Pannuti F, Skarlos D, Tomiak EM, Murawsky M, Alakl M, Aapro M. 304 Study Group: Prospective randomized trial of docetaxel versus mitomycin plus vinblastine in patients with metastatic breast cancer progressing despite previous anthracycline-containing chemotherapy. J Clin Oncol. 1999;17:1413-24.

11. Crown J: A review of the efficacy and safety of docetaxel as monotherapy in metastatic breast cancer. Semin Oncol. 1999;26(1 Suppl 3):5-9.

12. Ricci S, Boni G, Pastina I, Genovesi D, Cianci C, Chiacchio S, Orlandini C, Grosso M, Alsharif A, Chioni A, Di Donato S, Francesca F, Selli C, Rubello D, Mariani G. Clinical benefit of bone-targeted radiometabolic therapy with $153 \mathrm{Sm}$-EDTMP combined with chemotherapy in patients with metastatic hormone-refractory prostate cancer. Eur J Nucl Med Mol Imaging. 2007;34:1023-30.

13. Brito DMM, Gomes ML, Rodrigues PC, Paula EF, Gutfilen B, Bernardo-Filho M. Effect of the chemotherapeutic drugs on the biodistribution of 99mTc-DTPA in Balb/c mice. J Exp Clin Cancer Res. 1998;17:313-6.

14. Holanda CMCX, Leite RCH, Catanho MTJ, Souza GM, Bernardo-Filho $\mathrm{M}$. The effect of glucantime ${ }^{\mathrm{TM}}$ on the labeling of blood constituents with technetium-99m. Acta Cir Bras. 2005;20:81-5.

15. Chacon DA, Araújo-Filho I, Villarim-Neto A, Rêgo AC, Azevedo IM, Bernardo-Filho M, Brandão-Neto J, Medeiros AC. Biodistribution of the radiophamarceutical sodium pertechnetate $(\mathrm{Na99mTcO} 4)$ after massive small bowel resection in rats. Acta Cir Bras. 2007;22:430-5.

\section{Correspondence:}

Aldo Cunha Medeiros

Av. Miguel Alcides Araújo, 1889

59078-270 Natal - RN Brazil

aldo@ufrnet.br

Conflict of interest: none Financial source: $\mathrm{CNPq}$

Received: August 26, 2008

Review: October 28, 2008

Accepted: November 27, 2008

\section{How to cite this article}

Villarim Neto A, Açucena MKMT, Pereira KRSG, Rêgo ACM, Azevedo IM, Bernardo-Filho M, Medeiros AC. Biodistribution of samarium-153-EDTMP in rats treated with docetaxel. Acta Cir Bras. [serial on the Internet] 2009 Jan-Feb;24(1). Available from URL: http://www.scielo.br/acb 